\title{
PELATIHAN PEMBUATAN MIKRO ORGANISME LOKAL (MOL) UPAYA PENGEMBANGAN PADI ORGANIK DI DESA GLONGGONG BOYOLALI
}

\author{
Suswadi*, Wiyono, Achmad Fatchul Aziez, Dwi Susilo Utami, Haryuni, Sapto Priyadi. \\ Universitas Tunas Pembangunan Surakarta \\ *e-mail: suswadi_slo@yahoo.com
}

\begin{abstract}
Abstrak
Peranan Mikro Organisme Lokal (MOL) sebagai salah satu materi yang berguna bagi pertanian perlu mendapatkan perhatian dan adanya pengujian serta penelitian lebih lanjut. Sebagai Biofertilizer berbasis mikroorganisme diharapkan mampu memperbaiki struktur dan tekstur tanah, biologi tanah serta menyeimbangkan kembali ekosistem pertanian, baik lingkungan rhizosfer maupun lingkungan di atas rhizosfer. Artikel ini berupaya memberikan gambaran dan penjelasan terkait program kerja pembuatan MOL, meliputi proses, tahapan, hasil, dan manfaatnya. Penulisan artikel ini menggunakan pendekatan kualitatif dengan model deskriptif-eksplanatif. Hasilnya, masyarakat menerima pemahaman dan wawasan baru dalam hal pemanfaatan limbah tanaman dan limbah rumah tangga. Selain itu, petani dapat mengurangi penggunaan bahan pupuk organic dari luar dan juga pupuk organik pupuk buatan pabrik yang umumnya sudah banyak digunakan oleh petani di desa lain, sehingga dapat meminimalkan pengeluaran masyarakat petani desa dalam proses bercocok tanam. Artikel ini diharapkan dapat berkontribusi dalam keilmuan pertanian serta praktik dan strategi pengimplementasian pengembangan pertanian organik.
\end{abstract}

Kata Kunci : Mikro Organisme Lokal, Biofertilizer

\section{Abstract}

The role of local micro-organisms (MOL) as a useful material for agriculture needs attention and further testing and research. As a micro-organism-based biofertilizer, it is expected to be able to improve soil structure and texture, soil biology and rebalance agricultural ecosystems, both the rhizosphere environment and the environment above the rhizosphere. This article attempts to provide an overview and explanation regarding the work program for making MOL, including the process, stages, results, and benefits. The writing of this article uses a qualitative approach with a descriptive-explanative model. As a result, the community received new understandings and insights regarding the utilization of plant waste and household waste. In addition, farmers can reduce the use of organic fertilizers from outside and also factory-made organic fertilizers, which are generally widely used by farmers in other villages, so as to minimize the expenditure of rural farming communities in the farming process. This article is expected to contribute to agricultural science as well as practices and strategies for implementing the development of organic agriculture.

Keywords : Local microorganism, Biofertilizer

\section{PENDAHULUAN}

Pembangunan pertanian di Indonesia saat ini memasuki masa transisi dari orientasi pertanian dengan pola subsisten kepada pola komersial. Pergeseran tersebut membawa konsekuensi penggunaan pestisida sebagai salah satu komponen penting dalam mengatasi organisme pengganggu tanaman yang merupakan salah satu kendala bagi pembangunan pertanian yang berorientasi ekonomi. Namun sejauh ini pemakaian pestisida selalu diikuti dengan pertimbangan ekonomi dan dampaknya terhadap lingkungan.

Pasar lebih menyukai produksi pertanian yang bebas bahan kimia, sehingga alternatif pestisida aman bagi lingkungan dan konsumen sangat diperlukan. Pembatasan penggunaan bahan aktif kimiawi pada proses produksi pertanian pada gilirannya akan sangat membebani pertanian Indonesia yang tingkat ketergantungan petaninya pada pestisida kimiawi masih 
tinggi. Ketergantungan tersebut akan melemahkan daya saing produk pertanian Indonesia di pasar bebas. Menghadapi kenyataan tersebut agaknya perlu segera diupayakan pengurangan penggunaan pestisida kimiawi dan mengalihkannya pada jenis pestisida yang aman bagi lingkungan. Salah satu upaya adalah dengan pengembangan pertanian organik.

Padi merupakan salah satu varietas tanaman pangan yang dapat dibudidayakan secara organik. Pembudidayaan organik terlahir dari revolusi hijau yang merupakan upaya meningkatkan produksi pangan melalui usaha pengembanganteknologi pertanian yang meliputi penggunaan bibit unggul, penggunaan pupukkimia, penggunaan pestisida kimia, mekanisasi pertanian, dan penyuluhanpertanian secara massal. Revolusi hijau berkembang pesat dan mampu mencukupi kebutuhan pangan penduduk dunia pada awal dekade perkembangannya. Indonesia juga mengadopsi teknologi revolusi hijau dunia,hasilnya pada tahun 1984 Indonesia berhasil sebagai negara yang berswasembadapangan, namun revolusi hijau justru berdampak negatif, yaitu meningkatnyapenggunaan pupuk dan pestisida kimia yang dapat mencemari lingkungan dan menyebabkan keracunan pada manusia (Sriyanto, 2010). Konsumisi makanan organik seakan tengah menjadi tren dalam beberapa tahun terakhir ini. Masyarakat mulai beralih membeli produk-produk organik tertentusebagai bentuk kepedulian mereka terhadap kesehatan pribadi dan anggotakeluarganya. Tak hanya untuk buah dan sayuran, beras yang dihasilkan dari pertanaman padi secara organik pun kini mulai banyak dicari konsumen. Alasannya karena beras organik tidak hanya memiliki kualitas rasa yang enak,melainkan juga menyehatkan. Bahkan, sebagian konsumen beras organik, merekabeserta anggota keluarganya jarang sakit, kuantitas beras pun lebih hemat. Jikamengonsumsi beras anorganik, biasanya sampai $25 \mathrm{~kg}$ per bulan untuk empatorang, saat ini cukup $15 \mathrm{~kg}$ perbulan (Purwasamita, 2014)

Kelompok tani Unggul Jaya merupakan salah satu kelompok tani yang berada di desa Glonggong, Kecamatan Nogosari Kabupaten Boyolali. Telah mengembangkan pertanian organik sejak tahun 2007. Jenis tanaman utama yang dikembangkan adalan tanaman padi. Salah satu persyaratan dalam pengembangan pertanian organic adalah bahwa semua jenis sarana harus dijamin tidak tercemar bahan- bahan kimia yang di larang. Oleh sebab itu di kelompok tani Unggul Jaya, Desa Glonggong, Boyolali, telah mengembangkan kebutuhan sarana budidaya padi di usahakan secara mandiri.Untuk meningkatkan kapasitas kelompok tani dalam pengembangan bergam sarana usaha padi organik. Maka Fakultas Pertanian Universitas Tunas Pembangunan Surakarta telah melakukan pengabdian Masyarakat dengan melakukan pelatihan pembuatan MOL ( Mikro Organisme Lokal) biasa digunakan sebagai starter dalam pembuatan kompos atau bisa langsung di aplikasikan kelahan pertanian.

Kekhawatiran mengkonsumsi pangan yang mengandung residu pestisida serta rusaknya ekologis biotis suatu habitat oleh penggunaan pestisida yang berlebihan telah menjadi perhatian masyarakat, terutama lapisan masyarakat menengah ke atas. Potensi bahaya yang ditimbulkan oleh penggunaan pestisida dan pupuk anorganik yang berlebihan tersebut, direspon oleh sebagian masyarakat dengan gerakan pertanian organik, dengan meniadakan penggunaan pupuk organik dan pestisida. Gaya hidup sehat demikian telah melembaga secara internasional yang mensyaratkan jaminan bahwa produk pertanian harus beratribut aman dikonsumsi (food safety attributes), kandungan nutrisi tinggi (nutritionalattributes) dan ramah lingkungan (eco-labelling atributes). Preferensi konsumen seperti ini menyebabkan permintaan produk pertanian organik dunia meningkat pesat (Badan Penelitian dan Pengembangan Pertanian, 2005). 
Ada berbagai alasan pertanian organik menjadi kebijakan pertanian unggulan atau pendekatan penghidupan berkelanjutan. Pertanian organik mendorong perbaikan lima sumber daya yang dimiliki manusia, yaitu perbaikan sumber daya alam, perbaikan sumber daya sosial, perbaikan sumber daya ekonomi, dan perbaikan sumber daya infrastruktur (Saragih dan Eliyas, 2008).

Pertanian organik didefi nisikan sebagai "kegiatan usaha tani secara menyeluruh sejak proses produksi (prapanen) sampai pengolahan hasil (pascapanen) yang bersifat ramah lingkungan dan dikelola secara alami (tanpa penggunaan bahan kimia sintetis dan rekayasa genetika), sehingga menghasilkan produk yang dinilai lebih sehat dan bergizi” (IFOAM, 2002). Selanjutnya Nusril (2001), menyatakan bahwa sistem pertanian organik adalah suatu sistem pertanian holistik yang tidak menggunakan input sintetik (pupuk dan pestisida) dalam proses produksinya dimana manajemen produksi bertujuan meningkatkan kesehatan agroekosistem termasuk keanekaragaman hayati, siklus biologi, dan aktivitas biologi tanah untuk mengoptimalkan produksi tanaman. Pertanian organik merupakan pertanian masa depan sebagai usaha manusia menjaga kesehatan tubuh dan kelestarian alam dan lingkungan (Yusuf dan Fredi, 2001). Pertanian organik bertujuan untuk menghasilkan bahan yang memenuhi standar kualitas yang baik dan mendorong terjadinya daur biologis secara alami, yaitu dengan cara memanfaatkan sumber daya pertanian yang terbarukan (renewable) dan menerapkan praktik pertanian yang tidak menimbulkan pencemaran.

Sistem pertanian organik memberikan beberapa manfaaat diantaranya adalah: 1 . Tanaman menjadi sehat, bebas dari bahan kimia aktif, residu, baik dari akibat oleh pestisida ataupun pemupukan. 2. Hasil produksi akan lebih sehat. 3. Menjadi pertanian yang mampu menjaga kelestarian alam dan menjaga keseimbangan ekosistem.

Upaya pengembangan padi organik adalah untuk menghasilkan kemanfaatan tersebut diatas, selain itu untuk menghasilkan bahan pangan yang sehat, berupa beras organik.

Beras organik, yaitu beras yang tidak mengandung zat kimia berbahaya. Penggunaan pestisida kimia dan pupuk kimia dalam dalam budidaya padi organik diganti dengan pemakaian pestisida dan pupuk organik, sehingga pertanian organik tidak lagi mengandalkan pestisida kimia semata tetapi menggunakan pestisida hayati. Hal ini menunjukkan bahwa beras organik aman dari penggunaan zat kimia, sehingga relatif aman untuk dikonsumsi manusia karena seluruh proses produksinya ramah lingkungan dan meminimalkan input eksternal sintetik. Selain itu, rasa nasi dari beras organik lebih empuk, pulen dan daya simpannya lebih lama serta apabila sudah dimasak warnanya terlihat lebih putih.

Untuk pengembangan padi organic diperlukan pupuk organic yang berkualitas, pupuk organik merupakan pupuk yang tersusun dari sisa makhluk hidup, seperti pelapukan sisasisa tanaman, dan hewan. Pupuk organik ini dapat berbentuk padat maupun cair yang digunakan untuk memperbaiki sifat fisik, kimia, dan biologi tanah. kelebihan-kelebihan penggunaan pupuk organik yang sangat menguntungkan tanaman serta dapat memperbaiki kualitas tanah menjadi lebih kaya akan unsur hara, lebih gembur, dan bermanfaat dalam jangka waktu yang panjang. Untuk mendapatkan pupuk organik yang berkualitas, maka diupayakan pupuk organik dapat di produksi oleh kelompok tani secara mandiri. Salah satu kebutuhan utama dalam pembuatan pupuk organik diperlukan bakteri untuk fermentasi dalam proses pembuatan pupuk dengan mengembangkan Mikro Organisme Lokal (MOL) MOL adalah cairan yang terbuat dari bahan-bahan alami, sebagai media hidup dan berkembangnya mikroorganisme yang berguna untuk mempercepat penghancuran bahan organik. Mikro Organisme Lokal (MOL) adalah kumpulan mikro organisme yang bisa 
"diternakkan," fungsinya dalam konsep "zero waste" adalah untuk starter pembuatan kompos organik. Dengan MOL ini maka konsep pengomposan bisa selesai dalam waktu 3 mingguan (tiga minggu). Larutan MOL adalah larutan hasil fermentasi yang berbahan dasar dari berbagai sumberdaya yang tersedia setempat. Larutan MOL mengandung unsur mikro dan makro dan juga mengandung bakteri yang berpotensi sebagai perombak bahan organik, perangsang tumbuhan, dan sebagai agens pengendali hama dan penyakit tanaman. Fungsi MOL, meliputi: (a) Pupuk organik cair, (b) Decomposer atau biang pembuatan kompos, (c) Pestisida nabati.

Berikut adalah keunggulan dari pemanfaatan MOL: 1. Pembuatan MOL sederhana dan mudah dengan waktu yang relatif singkat. 2. Biaya pembuatan murah, karena menggunakan bahan-bahan yang kurang dimanfaatkan dan tersedia di sekitar. 3. Pupuk organik yang dihasilkan mengandung unsur kompleks baik makro maupun mikro serta mengandung mikroba yang bermanfaat.4. Ramah lingkungan karena tidak meninggalkan residu. 5. Biota tanah terlindungi sehingga dapat memperbaiki/ mempertahankan kualitas tanah. 6. Meningkatkan kuantitas dan kualitas produk hasil tanaman.

Banyak bahan baku disekitar kita yang dapat menghasilkan bahan organik dan mikroorganisme yang dapat memperbaiki kesuburan tanah. Selain mudah didapatkan juga murah, sehingga petani dapat menghasilkan pupuk sendiri dan tidak bergantung pada produsen pupuk. MOL adalah kumpulan organism bermanfaat yang dapat digunakan sebagai dekomposer, agens hayati dan pupuk mikroba bagi tanaman. Eksplorasi dan pengembangan Mol sangat mudah dilakukan. Batang pisang (Musa Parasidiaca) bisa digunakan sebagai sumber biakan, dan mikroorganisme yang menguraikan batang pisang ekologinya berasal dari sekitar perakaran atau batang pisang. Hasil penelitian menunjukan bahwa limbah batang pisang memiliki kandungan organik yang tinggi yaitu $83 \%$ dengan kandungan lignin dan selulosa sekitar 15-20\% serta hemiselulosase kitar 14,6\% (Kalia et al., 2000; Zhang et al., 2013).

Jenis mikrobia yang telah diidentifikasi pada MOL bonggol pisang antara lain Bacillus sp., Aeromonas sp., dan Aspergillus nigger. Mikrobia inilah yang biasa menguraikan bahan organik. Mikrobia pada MOL bonggol pisang akan bertindak sebagai dekomposer bahan organik yang akan dikomposkan. Selanjutnya, bonggol pisang mengandung karbohidrat sebesar 66,2g dalam $100 \mathrm{~g}$ bahan, bonggol pisang kering mengandung karbohidrat 66,2 g, dan pada bonggol pisang segar mengandung karbohidrat 11,6 g (Wulandari et al, 2009).

\section{METODE}

Metode pada pengabdian masyarakat ini menggunakan:

a). .Pelatihan

Pelatihan mempunyai pengertian yang diungkapkan oleh Simamora (Kamil, 2010) adalah "serangkaian aktivitas yang dirancang untuk meningkatkan keahlian-keahlian, pengetahuan, pengalaman, ataupun perubahan sikap seorang individu". Sedangkan tujuan dari pelatihan yang di ungkapkan oleh Dale S. Beach (1975) dalam (Kamil, 2010) adalah "the objective of training is to achive a change in the behavior of those trained (Tujuan pelatihan adalah untuk memperoleh perubahan dalam tingkah laku mereka yang dilatih)" .

b). Andragogi

Andragogi adalah proses pembelajaran yang melibatkan peserta didik dewasa ke dalam suatu struktur pengalaman belajar.. Istilah dewasa dalam Andragogi didasarkan atas kelengkapan 
kondisi fisik juga usia, dan kejiwaan, disamping itu pula orang dewasa dapat berperan sesuai dengan tuntutan tugas dari status yang dimilikinya. (Sintiawati, 2019)

c). Proses pembelajaran

Kegiatan pelatihan ini menggunakan proses pembelajaran partisipatif, yaitu sebagai upaya pembelajaran yang mengikutsertakan peserta didik dalam kegiatan pembelajaran. Menurut Sudjana (2005) keikutsertaan peserta didik diwujudkan dalam tiga tahapan kegiatan pembelajaran, yaitu: perencanaan program pembelajaran, pelaksanaan pembelajaran, dan penilaian pembelajaran

Tahapan pelatihan meliputi:

a) Pelasanaan kegiatan

Pelatihan pembuatan MOL ini dilakukan di kelompok tani Unggul Jaya di Desa Glonggong, Kecamatan Nogosari, Kabupaten Boyolali. Dilakukan pada tanggal 4 - 6 November 2021

b) Bahan dan Alat

Alat yang digunakan dalam pengabdian ini yaitu, pisau, ember dengan penutup, kayu pengaduk dan karung. Sedangkan bahan yang digunakan yaitu, batang pisang, terasi, ragi, air, air leri (air cucian beras) dan tetes.

c) Prosedur pembuatan

1) Pembuatan MOL

Bahan baku MOL berupa bonggol pisang, urin kelinci, air sisa cucian beras, tetes dan decomposer. Pembuatan MOL bonggol pisang dilakukan dengan mencampur $1 \mathrm{~kg}$ bonggol dengan 21 air sisa cucian beras , 1 gelas kecil tetes.

2) Pengolahan lahan

Tanah sebelum diolah digenangi kemudian dibajak sedalam 20-25 cm. Selanjutnya lahan digenangi air sedalam 3- $5 \mathrm{~cm}$ dan diberi pupuk dasar berupa kotoran ternak sapi yang sudah matang, setelah itu digaru sebagai pembentukan lumpur dan perataan. Selanjutnya lahan disemprot dengan MOL dengan konsentrasi satu gelas MOL dicampur dengan air sebanyak 17 liter. Langkah selanjutnya pembuatan petakan dan pengaturan jarak tanam $20 \times 20 \mathrm{~cm}$.

3) Pemelihara

Penyiangan dilakukan saat tanaman berumur 10, 20, 30, 40 hst secara manual. Pemberian MOL dilakukan dengan frekuensi setiap seminggu sekali.

\section{HASIL DAN PEMBAHASAN}

Kegiatan pelatihan pada kegiatan pengabdian ini di laksanakan pada tanggal 3 November 2021, di Desa Glonggong Kecamatan Nogosari Kabupaten Boyolali.. Kegiatan dilakukan dengan presentasi dan pelaksanaan praktik langsung serta tanya jawab. Pelatihan pembuatan Mikro Organisme Lokal (MOL) ini bertujuan menambah pengetahuan, wawasan dan ketrampilan petani terhadap pemahaman bahan local yang banyak ditemukan di sekitar sebagai bahan pembuatan MOL, dapat mengaplikasikan pengunaan MOL secara bersamasama ditingkat kelompok sehingga dapat mengurangi ketergantungan petani bahan dari luar sehingga dapat mengurangi biaya. Selain itu bahan-bahan MOL yang dibuat secara mandiri akan terjamin keorganikannya dan tidak kontaminasi dari bahan-bahan kimia.

Pelatihan pembuatan Mikro Organisme Lokal (MOL) ini pada pelaksanaannya menggunakan bahan alam yang terdapat didesa Glonggong dari bahan tanaman pisang yang sudah dipanen buahnya, sehingga hanya menggunakan bahan baku batang pisang yang sudah 
tidak bermanfaat. Tanaman pisang banyak dan mudah didapat dilingkungan desa, karena hamper semua petani menanam pisang. Karena itu pembuatan MOL ini menggunakan bahan yang tidak harus dibeli, selain itu bahan yang lain adalah air leri sisa air untuk cuci beras yang biasanya dibuang oleh ibu-ibu.

Pelaksanaan kegiatan ini dilakukan bersama anggota kelompok tani, yang dihadiri hampIr semua anggota kelompok tani, antusias petani-petani anggota kelompok dalam pembuatan ini sangat tinggi karena itu setiap sesi dilakukan dengan diskusi, namun petani anggota kelompok saat diskusi membandingkan nantinya hasil MOL apakah akan lebih baik pengaplikasianya dengan pupuk kimia, karena pupuk kimia mudah didapat dan mudah dalam pengaplikasiannya. Kegiatan ini bertujuan menimbulkan kepekaan petani terhadap bahan alam yang banyak ditemukan di sekitar lingkungan yang dapat di gunakan dalam kebutuhan sehari-hari seperti penggunaan pupuk organik,. Karena itu pada kegiatan pelatihan pembuatan Mikro Organisme Lokal (MOL) ini diharapkan agar petani anggota kelompok banyak alternatif dalam menggunakan pupuk organik padat maupun pupuk cair serta dapat mengoptimalkan dan mengaplikasikan penggunaan pupuk organik seperti MOL dalam skala kelompok.

Adapun kegiatan yang berhasil dilaksanakan dapat dilihat dalam dokumentasi berikut:
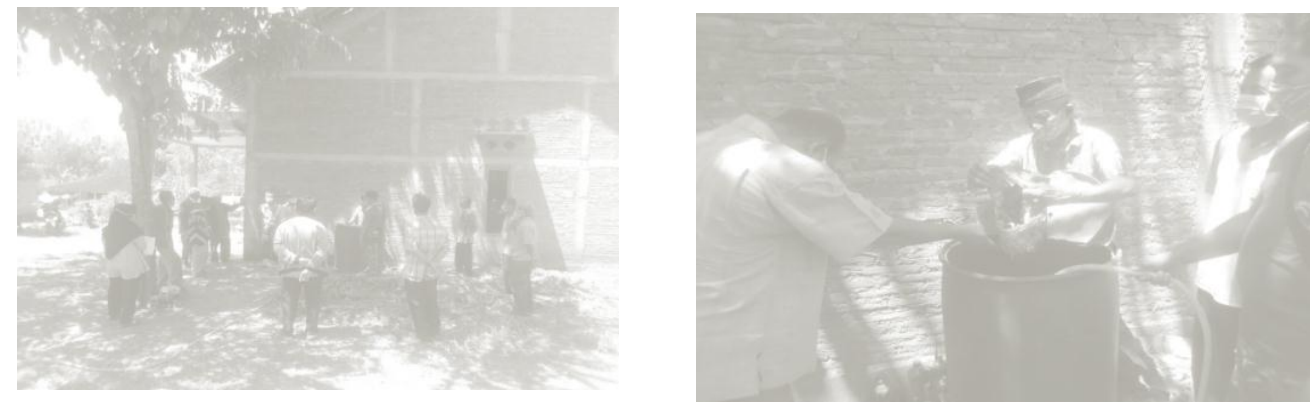

Gambar 1 : Praktek proses pembuatan MOL

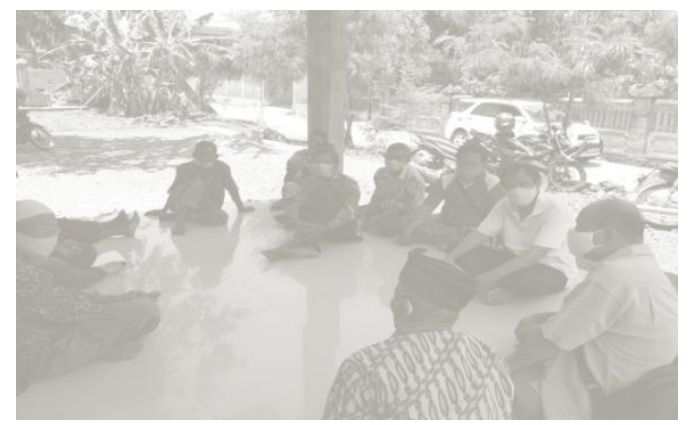

Gambar 2 : post-test bagi petani peserta pelatihan

Hasil dari kegiatan sosialisasi dan pelatihan ini adalah seluruh peserta tertarik dan antusias untuk menyimak dan mendengarkan materi tentang sampah serta ikut berpartisipasi langsung dalam pelatihan pembuatan MOL Peserta juga aktif bertanya terkait materi pembuatan MOL dan aplikasinya. Ketercapaian pelaksanaan kegiatan pengabdian masyarakat ini ditampilkan Dari hasil post-testyang ditunjukan pada gambar di bawah ini. 


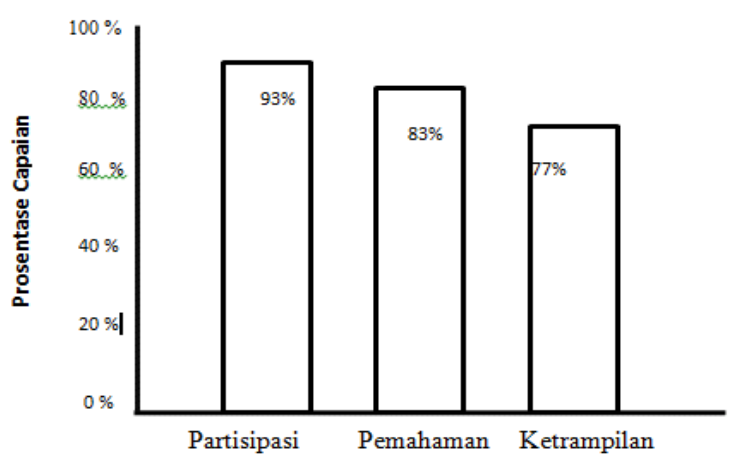

Gambar 3. Hasil capaian kegiatan pelatihan membuat MOL

Pada Gambar 3, tersebut terlihat bahwa partisipasi peserta dan keaktifan dalam diskusi pada petani yang hadir pada pelatihan pembuatan MOL mencapai $93 \%$. Hal ini sesuai dengan target bahwa tingkat partisipasi peserta pelatihan termasuk kategori sangat tinggi. Partisipasi adalah pelibatan seseorang atau beberapa orang dalam suatu kegiatan. Keterlibatan dapat berupa keterlibatan mental dan emosi serta fisik dalam menggunakan segala kemampuan yang dimilikinya (berinisiatif) dalam segala kegiatan yang dilaksanakan serta mendukung pencapaian tujuan dan tanggungjawab atas segala keterlibatan (Astuti, 2009). Partisipasi juga dipengaruhi oleh metodelogi yang dipilih dengan konsep proses pembelajaran partisipatif, sehingga meningkatkan minat petani untuk mengikuti pelatihan. Dengan adanya minat, maka akan muncul partisipasi dari peserta untuk mengikuti proses pembelajaran dengan serius dari awal sampai akhir. Hal ini sesuai dengan pendapat berikut yang menyatakan bahwa peserta memiliki minat yang sangat tinggi sehingga akan muncul partisipasi dari peserta untuk mengikuti pelatihan membuat MOL. Pelibatan seseorang atau beberapa orang dalam suatu kegiatan. Keterlibatan dapat berupa keterlibatan mental dan emosi serta fisik dalam menggunakan segala kemampuan yang dimilikinya (berinisiatif) dalam segala kegiatan yang dilaksanakan serta mendukung pencapaian tujuan dan tanggungjawab atas segala keterlibatan (Astuti, 2009).

Tingkat capaian pemahaman materi sudah baik yaitu sebanyak $83 \%$. Hal ini dapat dilihat dari hasil post-test yang telah dilakukan oleh petani peserta. Dari post-test tersebut, peserta sudah memahami MOL secara umum, jenis-jenis dan cara pembuatan MOL sehingga ada peningkatan pengetahuan yang diterima oleh para peserta terkait pembuatan MOL dan pengaplikasiannya pada tanaman padi. Dalam Taksonomi Bloom, pemahaman adalah kesanggupan memahami setingkat lebih tinggi dari pengetahuan. Namun, tidaklah berarti bahwa pengetahuan tidak dipertanyakan sebab untuk dapat memahami, perlu terlebih dahulu mengetahui atau mengenal. Pemahaman dalam pembelajaran adalah tingkat kemampuan yang mengharapkan seseorang mampu memahami arti atau konsep, situasi serta fakta yang diketahuinya. Dalam hal ini ia tidak hanya hapal secara verbalitas, tetapi memahami konsep dari masalah atau fakta yang ditanyakan, maka operasionalnya dapat membedakan, mengubah, mempersiapkan, menyajikan, mengatur, menginterpretasikan, menjelaskan, mendemonstrasikan, memberi contoh, memperkirakan, menentukan, dan mengambil keputusan. Pengertian pemahaman menurut Anas Sudijono, adalah kemampuan seseorang untuk mengerti atau memahami sesuatu setelah sesuatu itu diketahui dan diingat. Dengan kata lain, memahami adalah mengetahui mengetahui tentang sesuatu dan dapat melihatnya dari 
berbagai segi. Pemahaman merupakan jenjang kemampuan berpikir yang setingkat lebih tinggi dari ingatan dan hafalan. Sedangkan menurut Yusuf Anas, yang dimaksud dengan pemahaman adalah kemampuan untuk menggunakan pengetahuan yang sudah diingat lebih-kurang sama dengan yang sudah diajarkan dan sesuai dengan maksud penggunaannya. Dari berbagai pendapat di atas, indikator pemahaman pada dasarnya sama, yaitu dengan memahami sesuatu berarti seseorang dapat mempertahankan, membedakan, menduga, menerangkan, menafsirkan, memerkirakan, menentukan, memperluas, menyimpulkan, menganalisis, memberi contoh, menuliskan kembali, mengklasifikasikan, dan mengikhtisarkan.

Hasil capaian ketrampilan dalam pembuatan MOL dan pengaplikasianya pada budidaya tanaman padi juga dikategorikan baik yaitu mencapai $77 \%$. Nilai ini juga diukur dari posttest yang dilakukan setelah pelaksanaan pelatihan dan pelaksanaan budidaya tanaman padi organik. Menurut Gordon (1994) keterampilan merupakan kemampuan untuk mengoprasikan pekerjaan secara mudah dan cermat. Pada pengertian ini, biasanya cenderung pada aktivitas psikomotorik. Selain itu pengertian keterampilan menurut Nedler (1986) merupakan kegiatan yang memerlukan praktik dan dapat diartikan sebagai implikasi dari aktivitas.

Dari pelatihan pembuatan MOL ini, peserta sudah memahami bahan-bahan dan alatalat yang dibutuhkan serta tahapan dan cara kerja membuat MOL. Capaian pelatihan pada tingkat pemahaman dan ketrampilan belum mencapai $100 \%$ karena pada pelatihan tersebut, hasil MOL belum bisa dilihat sampai panen tapi bisa dilihat pada dampaknya di pertumbuhan tanaman padi. Program pengabdian masyarakat ini dapat dikatakan telah mampu meningkatkan pemahaman dan ketrampilan kepada petani anggota kelompok tani Unggul Jaya desa Glonggong Boyolali. Sehingga bisa menurunkan biaya usaha tani disertai dengan peningkatan kualitas hasil panen padi.

\section{KESIMPULAN}

Pelatihan pembuatan Mikro Organisme Lokal (MOL) ini bertujuan untuk menimbulkan kepekaan petani dalam menggunakan bahan alam yang bisa digunakan sebagai bahan pembuatannya. Kegiatan pelatihan pembuatan Mikro Organisme Lokal (MOL) ini dapat berjalan lancar, kegiatan ini di ikuti oleh petani anggota kelompok tani dengan seksama dalam memahami dan dapat di mengerti. Pelatihan pembuatan Mikro Organisme Lokal (MOL) dilaksanakan pada hari kamis, Jumat dan Sabtu, tanggal 4-6 November 2021 dan dilakukannya fermentasi selama satu minggu dalam fermentasi dilakukan pengadukan 3 hari sekali dalam masa fermentasi agar gas dalam ember dapat keluar serta bahan dapat bercampur dengan rata. Kemudian pembagian bahan MOL pada petani dilaksanakan pada dua minggu kemudian. Dan selanjutnya diaplikasikan pada tanaman padi petani masingmasing anggota kelompok. Dan pelaksanaannya berjalan dengan baik dan lancar setiap peserta diberikan bahan MOL sebanyak 300ml, dalam penggunaanya bahan MOL dicampurkan 1 gelas untuk bahan MOL dan 15/17 1 adalah air biasa). Campuran Mikro Organisme Lokal (MOL) selanjutnya di aplikasikan di lahan tanaman padi mulai pengolahan tanah dan pada pemeliharaan.

\section{DAFTAR PUTAKA}

Astuti, S. I. 2009. Desentralisasi dan partisipasi dalam pendidikan. Yogyakarta: UNY. 
Badan Penelitian dan Pengembangan Pertanian, 2005. Prospek Pertanian Organik Di Indonesian. http:// www. Litbang.DEptan.Goid/berita/one/17. [Diakses tanggal 11 Desember, 2015].

Basri, E dan Y. A. Fauziyah. Kompos dan Mol. http:/ /lampung.litbang.pertanian.go.id/ ind/images/stories/publikasi/brosur/komposmol.pdf

Gordon (1994). Teaching Skill. New York: Wesk Publishing Company

IFOAM. 2005. Prinsip-Prinsip Pertanian Organik. In: IFOAM General assembly, 2005 Adelaide. 1-4.

Kalia, V.C., Sonakya, V., Raizada, N. (2000). Anaerobic digestion of banana stem waste. Bio resource Technology. 73 (2) : 191-193.

Kamil, Mustofa. (2010). Model Pendidikan Dan Pelatihan (Konsep dan Aplikasi). Bandung: Penerbit Alfabeta

Nedler, Mac. (1986). Reading Skill and Media. New York: Wesk Publishing Company

Purwati, E. (2018). Pengaruh Media Tanam dan Pupuk Organik Cair Terhadap Pertumbuhan dan Produksi Bawang Merah (Allium ascalonicum L.). Bandar Lampung (ID): Universitas Lampung.

Purwasasmita, M. 2014. Padi SRI Organik Indonesia. Penerbar Swadaya.Jakarta.

Saragih. dan S Eliyas. (2008). Pertanian Organik Solusi Hidup Harmoni dan Berkelanjutan. Jakarta : Penebar Swadaya.

Sriyanto, S., 2010. Panen Duit dari Bisnis Padi Organik. Agro Media. Jakarta Selatan.

Sudjana, N. (2005). Penilaian Hasil Proses Belajar Mengajar. Bandung: Rosdakarya

Sintiawati S., Saktika Rohmah Fajarwati, 2019, Partisipasi Orang Dewasa Dalam Sebuah Pelatihan, Indonesian Journal Of Adult and Community Education, Vol. 1, No. 1, hal 26-30

Tarmo. 2008. Cara Jitu Membuat Kompos dan MOL. https://organicfield.wordpress.com/ 2008/09/27/cara-jitu-membuat-kompos-dan-mol/

Wulandari DDN, Fatmawati EN, Qolbaini KE, Praptinasari S. (2009). Penerapan MOL (Mikroorganisme Lokal) Bonggol Pisang sebagai Biostarter Pembuatan Kompos. PKM-P. Surakarta (ID): Universitas Sebelas Maret.

Yusril, 2001. Perspektif Pemasaran Dari Pembangaunan Pertanian Organik Di Propinsi Bengkulu. Makalah disampaikan pada pembekalan Program Semi Que III fakultas Pertanian Universitas Bengkulu. Juli 2001. Bengkulu..

Yusuf, dan S. Fredi. 2001. Membentuk Masyarakat Pertanian Organik Di Propinnsi Bengkulu. Fakultas Pertanian Universitas Bengkulu. Bengkulu.

Zhang, C., Li, J., Liu, C., Liu, X., Wang, J., Li, S., Fan, G., Zhang, L. (2013). Alkaline pretreatment for enhancement of biogas production from banana stem and swine manure by anaerobic codigestion. Bioresource Technology. 149: 353-358. 